\title{
Air pollution data in COVID-19 time: A call for improving
} availability and accessibility

\section{Cleonilde Nascimento ${ }^{1,2}$, Sheilla Oliveira ${ }^{2}$, Helotonio Carvalho $^{1,2}$}

${ }^{1}$ Department of Biophysics and Radiobiology, Biological Sciences Centre, Federal University of Pernambuco, Recife, Brazil ${ }^{2}$ Department of Immunology, Aggeu Magalhães Institute (IAM), Oswaldo Cruz Foundation (FIOCRUZ), Recife, Brazil

According to $\mathrm{WHO}$, air pollution causes 7 million deaths a year, however many cities do not monitor air pollution or do not make data available.
Lockdowns had a huge impact on people's lives, making home-office the rule, closing schools, restaurants, and non-essential stores, and ultimately, saving millions of lives. The decrease in economic activities and transportation had a positive side effect, reducing air pollution in many cities/countries [3-5]. Air pollution causes more than 7 million deaths each year and particulate matter (PM) is the component most associated with health problems, such as ischaemic heart disease, lung cancer, cerebrovascular disease, chronic obstructive pulmonary disease and lower respiratory infections $[6,7]$.

COVID-19 effects on air pollution levels raised a question about air quality data accessibility. The last update for the Air Quality Database from the World Health Organization (WHO) lists PM data for 4300 cities in 108 countries, comprising data from 9690 air quality monitoring stations [8]. Most stations are located in USA, Europe, Japan and China and the total number of stations and cities monitored in the world is, in fact higher comprising more than 15000 air quality monitoring stations in over 6000 cities [9]. At least partly, the differences between the numbers in these two reports may reflect data accessibility. Access to historical air pollution data varies widely and many cities around the world do not make data readily available. For those cities which have historical air pollution data and make them available, the way they are provided, and their accessibility is highly variable. Table 1 compares air quality data availability for 23 selected cities, in different regions of the world and different levels of air pollution. Islamabad has no city-specific website and the national one 
Table 1. Comparison of air quality data accessibility in different cities of the world

\begin{tabular}{|c|c|c|c|c|c|c|c|c|}
\hline 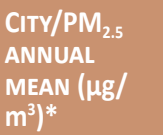 & $\begin{array}{l}\text { LIVE DATA/ } \\
\text { HISTORICAL } \\
\text { DATA SETS }\end{array}$ & $\begin{array}{l}\text { DATA } \\
\text { SETS FOR } \\
\text { INDIVIDUAL } \\
\text { STATIONS }\end{array}$ & $\begin{array}{l}\text { SEARCH FOR } \\
\text { ALL STATIONS/ } \\
\text { POLLUTANTS AT } \\
\text { ONCE }\end{array}$ & $\begin{array}{l}\text { TIME FRAME } \\
\text { AVAILABILITY } \\
\left(\text { PM }_{2.5}\right)^{\dagger}\end{array}$ & $\begin{array}{l}\text { RESTRICTION } \\
\text { FOR TIME } \\
\text { FRAME } \\
\text { SEARCH }\end{array}$ & $\begin{array}{l}\text { PAGE IN } \\
\text { ENGLISH/ } \\
\text { DATA } \\
\text { SEARCH }\end{array}$ & $\begin{array}{l}\text { ADDITIONAL } \\
\text { FEATURES/ } \\
\text { ISSUES }\end{array}$ & WeBsite \\
\hline Adelaide (7) & $\begin{array}{l}\text { Yes/Yes (csv } \\
\text { files) }\end{array}$ & Yes & No & 2013-To date & None & NA & & https://www.epa.sa.gov.au \\
\hline Auckland (6) & $\begin{array}{l}\text { Yes/Yes (csv } \\
\text { files) }\end{array}$ & Yes & No/No & Not evaluated & None & NA & $\begin{array}{l}\text { Website not user } \\
\text { friendly }\end{array}$ & $\begin{array}{l}\text { https://environmentauckland. } \\
\text { org.nz }\end{array}$ \\
\hline Beijing (73) & $\begin{array}{c}\text { Yes/Not } \\
\text { evaluated }\end{array}$ & $\begin{array}{c}\text { Not } \\
\text { evaluated }\end{array}$ & Not evaluated & Not evaluated & Not evaluated & No/NA & $\begin{array}{l}\text { Website cannot } \\
\text { be translated }\end{array}$ & http://zx.bjmemc.com.cn \\
\hline Berlin (16) & $\begin{array}{l}\text { Yes/Yes (csv } \\
\text { files) }\end{array}$ & Yes & No/Yes & 2016-To date & ly at a time & Yes/No & Data in graphs & https://uftdaten.berlin.de/lqi \\
\hline $\begin{array}{l}\text { Buenos Aires } \\
\text { (N/A) }\end{array}$ & $\begin{array}{l}\text { No/Yes (pdf } \\
\text { files) }\end{array}$ & Yes & No/Yes & $\begin{array}{l}\text { 2010-To date } \\
\left(\mathrm{PM}_{10}\right) \text {. No } \\
\mathrm{PM}_{2.5} \text { data }\end{array}$ & $1 \mathrm{mo}$ at a time & No & $\begin{array}{l}\text { 2-mo delay on } \\
\text { reports }\end{array}$ & $\begin{array}{c}\text { https://www.buenosaires.gob.ar/ } \\
\text { agenciaambiental }\end{array}$ \\
\hline Dubai (54) & $\begin{array}{l}\text { Yes/Upon } \\
\text { payment }\end{array}$ & $\begin{array}{c}\text { Not } \\
\text { evaluated }\end{array}$ & Not evaluated & Not evaluated & Not evaluated & Yes/NA & & $\begin{array}{c}\text { http://www. } \\
\text { dubaiairenvironment.dm.gov.ae }\end{array}$ \\
\hline $\begin{array}{l}\text { Islamabad } \\
(66)\end{array}$ & $\mathrm{No} / \mathrm{No}$ & NA & NA & NA & NA & Yes/No & & $\begin{array}{l}\text { http://www.environment.gov. } \\
\text { pk/index.php }\end{array}$ \\
\hline $\begin{array}{l}\text { Johannesburg } \\
(41)\end{array}$ & $\begin{array}{l}\text { Yes (AQI)/Yes } \\
\text { (xls files) }\end{array}$ & Yes & Yes/Yes & 2016-To date & None & NA & $\begin{array}{c}\text { Lack of } \\
\text { continuous data }\end{array}$ & $\begin{array}{c}\text { https://saaqis.environment.gov. } \\
\text { za/home/index }\end{array}$ \\
\hline London (12) & $\begin{array}{l}\text { Yes/Yes (csv } \\
\text { files) }\end{array}$ & Yes & $\begin{array}{c}\text { Up to } 6 \\
\text { stations/No }\end{array}$ & 2009-To date & None & NA & $\begin{array}{l}\text { Data in graphs; } \\
\text { different times } \\
\left(15^{\prime}-24 \mathrm{~h}\right)\end{array}$ & https://www.londonair.org.uk \\
\hline $\begin{array}{l}\text { Los Angeles } \\
\text { (12) }\end{array}$ & $\begin{array}{l}\text { Yes/Yes (csv } \\
\text { files) }\end{array}$ & Yes & Yes/No & 1999-To date & $1 \mathrm{y}$ at a time & NA & & https://ww2.arb.ca.gov \\
\hline $\begin{array}{l}\text { Mexico City } \\
(22)\end{array}$ & $\begin{array}{l}\text { Yes/Yes (csv } \\
\text { files) }\end{array}$ & $\begin{array}{c}\text { Data sets } \\
\text { contain all } \\
\text { stations } \\
\end{array}$ & Yes/Yes & 2003-To date & None & No/NA & & http://www.aire.cdmx.gob.mx \\
\hline Milan (27) & $\begin{array}{l}\text { Yes/Yes (csv } \\
\text { files) }\end{array}$ & Yes & $\begin{array}{l}\text { No/5 pollutants } \\
\text { at a time }\end{array}$ & 2007-To date & ly at a time & No/NA & $\begin{array}{l}\text { Data sent by } \\
\text { email; search is } \\
\text { troublesome }\end{array}$ & https://www.arpalombardia.it \\
\hline Moscow (14) & $\begin{array}{l}\text { Yes/Yes (csv } \\
\text { files). }\end{array}$ & $\begin{array}{l}\text { Data sets } \\
\text { contain all } \\
\text { stations } \\
\end{array}$ & Yes/Yes & Not evaluated & None & Yes/NA & $\begin{array}{l}\text { Data in graphs; } \\
\text { search is } \\
\text { troublesome. }\end{array}$ & $\begin{array}{l}\text { https://mosecom.mos.ru (live } \\
\text { data); https://data.mos.ru/ } \\
\text { (historical data) }\end{array}$ \\
\hline $\begin{array}{l}\text { New Delhi } \\
\text { (143) }\end{array}$ & $\begin{array}{l}\text { Yes/Yes (csv } \\
\text { files) }\end{array}$ & Yes & Yes/Yes & Not evaluated & None & Yes/Yes & $\begin{array}{l}\text { Data at different } \\
\text { times ( } 15 \mathrm{~min}- \\
24 \mathrm{~h}) \\
\end{array}$ & https://app.cpcbccr.com \\
\hline New York (7) & $\begin{array}{l}\text { Yes/Yes (xls } \\
\text { files) }\end{array}$ & Yes & Yes & 2015-To date & None & NA & $\begin{array}{l}\text { Older data: US } \\
\text { EPA website }\end{array}$ & $\begin{array}{l}\text { http://www.nyaqinow.net; } \\
\text { https://www.epa.gov/outdoor- } \\
\text { air-quality-data (older data) }\end{array}$ \\
\hline Paris (16) & $\begin{array}{l}\text { Yes/Yes (csv } \\
\text { files) }\end{array}$ & $\begin{array}{c}\text { Data sets } \\
\text { contain all } \\
\text { stations }\end{array}$ & $\begin{array}{l}\text { Yes, download } \\
\text { station or } \\
\text { pollutant data }\end{array}$ & 1999-To date & None & No/No & & https://www.airparif.asso.fr \\
\hline Rome (15) & $\begin{array}{l}\text { Yes/Yes (pdf } \\
\quad \text { files) }\end{array}$ & $\begin{array}{l}\text { Only for } \\
\text { real-time } \\
\text { data }\end{array}$ & Yes/No & 1999-To date & $1 \mathrm{y}$ at a time & Yes/NA & $\begin{array}{l}\text { Search is } \\
\text { troublesome }\end{array}$ & http://www.arpalazio.gov.it \\
\hline Santiago (29) & $\begin{array}{l}\text { Yes/Yes (csv } \\
\text { files) }\end{array}$ & Yes & $\begin{array}{c}\text { No/No } \\
\text { downloaded } \\
\text { separately } \\
\end{array}$ & 1997-To date & None & No & Data in graphs & https://sinca.mma.gob.cl \\
\hline $\begin{array}{l}\text { São Paulo } \\
(17)\end{array}$ & $\begin{array}{l}\text { Yes/Yes (csv } \\
\text { files) }\end{array}$ & Yes & $\begin{array}{l}\text { l station } / 3 \\
\text { pollutants a } \\
\text { time }\end{array}$ & Not evaluated & $1 \mathrm{y}$ at a time & No & $\begin{array}{l}\text { Requires } \\
\text { registration }\end{array}$ & https://qualar.cetesb.sp.gov.br \\
\hline Seoul (26) & $\begin{array}{l}\text { Yes/Yes (CSV } \\
\text { files), but in } \\
\text { Korean }\end{array}$ & Yes & No/Yes & 2013-To date & $2 \mathrm{mo}$ at a time & Yes/No & $\begin{array}{c}\text { Hard to navigate; } \\
\text { search is } \\
\text { troublesome }\end{array}$ & https://www.airkorea.or.kr \\
\hline Sydney (8) & $\begin{array}{l}\text { Yes/Yes (csv } \\
\text { files) }\end{array}$ & Yes & Yes/Yes & 2012-To date & None & NA & & https://www.dpie.nsw.gov.au \\
\hline Tokyo (17) & $\begin{array}{l}\text { Yes/Yes but in } \\
\text { Japanese }\end{array}$ & $\begin{array}{c}\text { Not } \\
\text { evaluated }\end{array}$ & Not evaluated & 2000-To date & None & Yes/No & $\begin{array}{l}\text { 6-mo delay on } \\
\text { reports; website } \\
\text { cannot be } \\
\text { translated }\end{array}$ & $\begin{array}{l}\text { https://www.kankyo.metro. } \\
\text { tokyo.lg.jp }\end{array}$ \\
\hline $\begin{array}{l}\text { Venice } \\
(26) \\
\end{array}$ & $\begin{array}{c}\text { Yes/Only } \\
\text { daily bulletins }\end{array}$ & Yes & Yes & 2010-To date & Not evaluated & No/NA & $\begin{array}{l}\text { Data upon } \\
\text { request (csv files) }\end{array}$ & https://www.arpa.veneto.it \\
\hline
\end{tabular}

N/A - not applicable, y - year, mo - months, min - minutes

*PM 2.5 data from WHO Global Ambient Air Quality Database, 2018, https://www.who.int/airpollution/data/cities/en/, except for Dubai, which was calculated from [8].

$†$ Time frame availability was analysed for $\mathrm{PM}_{2.5}$ data. Data for other pollutants usually have larger time coverage. 


\section{Detailed air quality data should be freely available to improve trans- parency and data availability. Cities/ countries should work on providing either an English webpage or a web- site which can be translated by com- mon web browsers. A global service with historical data from all the avail- able stations on the world would be the ideal solution.}

has only limited information. For Dubai, anyone who wants to access the data needs to make a payment to the Dubai Municipality. Each pollutant is charged separately and the longer the time frame for the data the higher is the fee amount. For $\mathrm{PM}_{2.5}$ (particulate matter below $2.5 \mu \mathrm{m}$ in diameter), for example, each month of data costs about US\$400.00.

Time frame availability, evaluated for $\mathrm{PM}_{2.5}$, varies widely. While some cities have data since the late 1990s, others have only after 2010s. For Berlin, many air quality monitoring stations started measuring $\mathrm{PM}_{2.5}$ in 2008 , but only data from 2016-To date are available, probably a temporary issue in order to revise older data. Buenos Aires has no $\mathrm{PM}_{2.5}$ historical data, while they are discontinuous for Johannesburg. Data output format can also be a problem. This is the case for Buenos Aires and Rome, since data are only available as reports in pdf files, instead of Excel or CSV, which makes it more difficult to work with them.

In some cases, the absence of an English webpage or its limited functionality is a real problem. This issue can sometimes be overcome with automatic translation functions available in internet browsers. However, it is often impossible to access air pollution data. This is the case for Beijing. The information is apparently there, but translation engines are not able to translate them. In this case, websites that mirror some air pollution data in China and can be automatically translated, such as China's air quality online monitoring and analysis platform-AQI [10] may be a way to get some data. Japan is the country with the largest coverage of air quality stations per area [9]. However, Tokyo air quality website makes it virtually impossible to access the data without knowing Japanese. There is an English webpage but with only limited functions. For Seoul, the English webpage has no data search function. The Korean website, when accessed by browser translation, is difficult to navigate and find the data, especially for individual air monitoring stations. For Moscow, interestingly, current year data can be visualized in graphs for each air quality monitoring stations and air pollutant but cannot be downloaded. Data download is possible in another website which has an English webpage. However, search is troublesome, and data are downloaded partially in English and partially in Russian.

Despite the absence of English versions, some websites work well with browser translation and may be accessible for people who do not speak the original language. This is the case for Venice, Milan, Rome, Madrid, Mexico City, Buenos Aires, and São Paulo. Berlin has an English webpage but with no data search function though the German website can be translated enabling data search. For Paris, the website available until early 2021, had an English webpage with the same functions as the French website. Unfortunately, the new website does not have an English version anymore. Finally, São Paulo is the only city which requires registration to access the data. As examples of data availability and accessibility, it is noteworthy to mention London and New Delhi websites which are easy to navigate and allow download of data with different time intervals from 15 minutes to 24 hours.

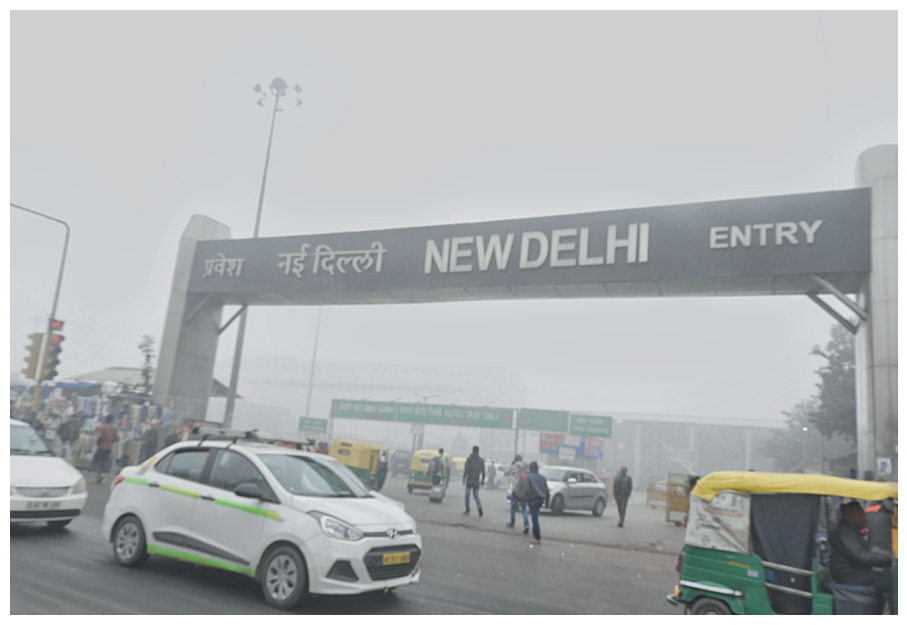

Photo: Low visibility due to smog at New Delhi railway station (Sumita Roy Dutta, via Wikimedia Commons).
The purpose here was to compare air pollution data accessibility in different cities around the world. Despite some good examples, many cities need to improve data accessibility. Seoul, Tokyo, and Beijing, some of the cities with major problems in air pollution data accessibility due to language issues, would benefit from the experience from cities like London and New Delhi. Islamabad, one of the most polluted capitals in the world, should give priority to improving data transparency. Besides Islamabad, many other highly polluted cities in Southeast Asia or the Middle East do not have any record of official air quality monitoring. These include Peshawar, another Pakistan city, Ulaanbaatar, Kabul, Manama, and Kathmandu. For all of them, except Kabul, US Embassies and Consulates are a helpful alternative data source since they have their own air quality monitoring [11]. Other agencies like US Environmental Protection Agency (EPA) and European Environmental Agency (EEA) provide data access for several US and European cities, respectively $[12,13]$. Despite their value, it is not always possible to search for specific air quality monitoring stations or identify them. 
Air quality depends on monitoring, data availability, and policies to decrease air pollution levels, which help to reduce health problems and deaths caused by air pollution. Changes in air pollution, caused by COVID-19 pandemics, brought air quality to attention of the public and governments, which should be used to speed up the adaptation of agencies like US EPA and EEA to allow more detailed air quality data search. Besides this, it should also induce cities/countries to improve transparency and provide English webpages with full data access. Finally, a global service which would be updated in real-time with historical data from air quality monitoring stations from all over the world, like the Johns Hopkins University website for COVID-19, would be a really useful tool, which would greatly increase transparency and accessibility to air quality data.

Funding: No funding was used for this study.

Authorship contributions: HC created the initial concept for the article. HC and CN performed literature search, data collection and interpretation. SO contributed on data revision. HC wrote the first draft of the manuscript and all the authors contributed to writing, revision, and approval of the final manuscript. All authors meet the ICMJE criteria for authorship.

Competing interests: The authors completed the ICMJE Unified Competing Interest form (available upon request from the corresponding author), and declare no conflicts of interest.

1 Johns Hopkins University \& Medicine. Coronavirus Resource Center. Available: https://coronavirus.jhu.edu/map.html. Accessed: 28 June 2021.

2 Dong E, Du H, Gardner L. An interactive web-based dashboard to track COVID-19 in real time. Lancet Infect Dis. 2020;20:5334. Medline:32087114 doi:10.1016/S1473-3099(20)30120-1

3 European Space Agency. 2020. Coronavirus lockdown leading to drop in pollution across Europe. Available: https://www. esa.int/Applications/Observing_the_Earth/Copernicus/Sentinel-5P/Coronavirus_lockdown_leading_to_drop_in_pollution_ across_Europe. Accessed: 25 May 2021.

4 Mahato S, Pal S, Ghosh KG. Effect of lockdown amid COVID-19 pandemic on air quality of the megacity Delhi, India. Sci Total Environ. 2020;730:139086. Medline:32375105 doi:10.1016/j.scitotenv.2020.139086

5 Chen K, Wang M, Huang C, Kinney PL, Anastas PT. Air pollution reduction and mortality benefit during the COVID-19 outbreak in China. Lancet Planet Health. 2020;4:e210-2. Medline:32411944 doi:10.1016/S2542-5196(20)30107-8

6 World Health Organization. Air Pollution. Available: https://www.who.int/health-topics/air-pollution\#tab=tab_1. Accessed: 28 May 2021.

7 Cohen AJ, Brauer M, Burnett R, Anderson HR, Frostad J, Estep K, et al. Estimates and 25-year trends of the global burden of disease attributable to ambient air pollution: an analysis of data from the Global Burden of Diseases Study 2015. Lancet. 2017;389:1907-18. Medline:28408086 doi:10.1016/S0140-6736(17)30505-6

8 World Health Organization. Air quality database (Update 2018). Available: https://www.who.int/data/gho/data/themes/airpollution/who-air-quality-database. Accessed: 28 June 2021.

9 Carvalho H. The air we breathe: differentials in global air quality monitoring. Lancet Respir Med. 2016;4:603-5. Medline:27423918 doi:10.1016/S2213-2600(16)30180-1

$10 \mathrm{AQI}$ - China's air quality online monitoring and analysis platform. Available: https:/www.aqistudy.cn/. Accessed date: 25 May 2021.

11 AirNow - US Department of State. Available: https://www.airnow.gov/international/us-embassies-and-consulates/. Accessed: 25 May 2021.

12 European Environmental Agency. Air pollution. Available: https://www.eea.europa.eu/themes/air. Accessed: 26 May 2021

13 United States Environmental Protection Agency. Air Data: Air Quality Data Collected at Outdoor Monitors Across the US. Available: https://www.epa.gov/outdoor-air-quality-data. Accessed: 26 May 2021.

\section{Correspondence to:}

Prof. Helotonio Carvalho

Department of Biophysics and Radiobiology

Biological Sciences Centre

Federal University of Pernambuco

Av. Prof. Moraes Rego, s/n

Cidade Universitária, 50670-901

Recife - PE

Brasil

helotonio.carvalho@ufpe.br 